UDK 504.38

Article info

Received 22.02.2017 p.

\title{
CLIMATE FINANCE IN THE CONTEXT OF THE PARIS AGREEMENT: OPPORTUNITIES AND CAUTIONS FOR UKRAINE
}

\begin{abstract}
The adoption of the Paris Agreement (UNFCCC, 2015) marked the beginning of a new phase in the search for responses to climate change. In particular, the agreement made important adjustments to the architecture and procedures of international climate finance, as one of the key instruments for supporting necessary measures. Building on systematic review of recent scientific literature, analytical reports and publicly available official information on climate finance, the article discusses key changes in the sphere, taking place after the adoption of agreement and their relevance to Ukraine, where high expectations regarding climate finance come from the government, business and public. Given the polarized climate policy in Ukraine, the emphasis is placed on the important nuances of the emerging climate finance, those that often go unnoticed by analysts and researchers, namely - a clear need for alternatives to emissions offsetting, the importance of developing a system for recognizing, monitoring and verification of the effectiveness of adaptation measures, and need for solutions outside of the decarbonization policy and the respective funding priorities. Based on international experience, I offer to consider climate finance and other economic instruments as solutions, which, along with their potential effectiveness, are not a panacea. Climate finance should create synergies in the system of climate change measures, but also should not become a barrier or "veil" to systemic change in society, one that requires changes much more profound, than the allocation and proper use of sufficient funds. Financing climate action should consider not only "hard" solutions, but also investments into and nurturing of social and cultural innovation and experimentation, which are at the roots of necessary change. Climate finance shall only be effective when public deliberation and participation becomes a foundation for all other action.
\end{abstract}

Ключові слова: climate finance; carbon markets; decarbonization policy; international cooperation.

Introduction. Climate change is among the most serious issues life on Earth currently faces. While the process is long-term, urgent and continuous action is needed to reverse, prevent and mitigate what is possible and to prepare for the unavoidable. This article focuses on climate finance, as one of the acclaimed and promising ways of supporting solutions to climate change challenges (OECD, 2016a).

The article provides an overview of the changes in the climate finance architecture since adoption of the Paris agreement and suggest ways to use the new finance setting for addressing climate change in Ukraine. The work is relevant considering polarized, while insufficiently nuanced climate policy debates in Ukraine - with fossil fuel lobby and disregard of need to drastically increase Nationally Determined Contributions (NDCs) on one side and enthusiastic fervour for any type of international climate finance, which is seen almost as panacea for all the climate threats - on the other. Here, more thorough considerations are suggested for exploring climate finance opportunities in Ukraine, along with suggestions to ways to avoid unfavourable choices in the near future.

This article builds on analytical reports of international organizations, scientific papers from Scopus database, and publicly available official reports focusing on climate finance broadly and particularly regarding Ukraine's context, published mostly during the last two years, however also relevant literature published from earlier years.

\section{Climate finance landscape}

Climate finance background. A comprehensive definition of climate finance comes from Climate Policy Initiative, which explains it as "financial resources paid to cover the costs of transitioning to a low-carbon global economy and to adapt to, or build resilience against, current and future climate change impacts" (Falconer \& Stadelmann, 2014). Climate finance concerns with who, where, using which instruments and into which projects/solutions money is invested. Comprehending and tracking climate finance allows to reveal patterns, showing for example what projects or instruments have steadily delivered effective outcomes, where the hotspots of climate innovation lie or how opportunities can be best used in particular situations. It can also support more effective and fair climate change action, helping the most vulnerable to adapt faster, as well as to channel money for mitigation where it is most needed (CBM, 2016).

Global climate finance: novel instruments and the expansion of green bonds. Ratification of the Paris Agreement in 2016 has put climate action, renewable energy and sustainable technologies into the forefront of global investments. Article 2(1) of the agreement states that nations commit to "Making finance flows consistent with a pathway towards low greenhouse gas emissions and climate-resilient development" (UNFCCC, 2015). Article 9 states that "Developed country Parties shall provide financial resources to assist developing country Parties with respect to both mitigation and adaptation in continuation of their existing obligations under the Convention" (UNFCCC, 2015). In Paris countries confirmed its prior commitment to mobilize USD 100 billion annually till 2020, with aims of further increasing this amount. While disputes remain on the promises and failures of the Paris Agreement, it is evident the treaty made some critical contributions to the changes in climate finance landscape. Paris Agreement is a child of a

Цитування за ДСтУ: Soloviy V. I. Climate finance in the context of the Paris Agreement: opportunities and cautions for Ukraine /

V. I. Soloviy // Науковий вісник НЛтУ України. Серія економічна. - 2017. - Вип. 27(2). - С. 38-41.

Citation APA: Soloviy, V. I. (2017). Climate finance in the context of the Paris Agreement: opportunities and cautions for Ukraine. Scientific Bulletin of UNFU. Economic Series, 27(2), 38-41. Retrieved from:

http://nv.nltu.edu.ua/index.php/journal/article/view/358 
time and context much different from the Kyoto Protocol while the world is still divided by the levels of development, now all signatories shall make climate commitments and set targets, with 165 countries so far submitting the intended nationally determined contributions (INDCs).

The climate finance architecture is going through multiple changes considering failures of the Kyoto Protocol mechanisms. A recent EU study (Cames et. al, 2016) on Clean Development Mechanism (CDM) effectiveness draw a conclusion that $73 \%$ of potential CDM credits supplied between 2013 and 2020 are not likely to provide "real, measurable and additional" reductions in emissions, while they can lead to 3.5 billion tones $\mathrm{CO}_{2}$ emissions increase within this period. A similar study by Stockholm Environment Institute (Kollmuss, Schneider \& Zhezherin, 2016) showed 600 million tones increased emissions from Joint Implementation scheme. If we want new mechanisms of Paris Agreement to be effective, we will have to carefully consider previous experiences.

Paris Agreement comes with two new instruments - Cooperative Approaches (CA) and Sustainable Development Mechanism (SDM). The SDM was designed to replace the $\mathrm{CDM}$ and JI, aiming at public and private participants implementing activities that mitigate climate change inside a host country. Meanwhile, Cooperative Approaches allow country-to-country transfer of mitigation outcomes. SDM comes as a new promising instrument for climate finance, focusing both on emissions reduction and broader sustainable development goals. Comparing SDM and CDM, the key recommendations that come from Carbon Market Watch include withdrawing carbon offsetting from the Paris Agreement, focusing on results-based finance and establishing effective transition process to SDM. So far it is too early to make statements about the prospects of the future architecture, since the procedures are yet to be developed. At this points critical issues remain with categorizing and evaluating (Roberts \& Weikmans, 2017) as well as reporting and verification of climate finance (Xu, Dong \& Wang, 2017).

Outside Paris Agreement, another emerging and promising field of climate finance - green bonds market is rapidly growing, with 900 million USD in 2009, it had shifted to 11 billion USD in 2013 and 81 billion USD in 2016, with expectations for 150 billion in 2017 (www.climatebonds.net). The scheme may be particularly interesting for financing transformations in urban settings, as it has been successfully demonstrated by Gothenburg Sweden. The city has issued first green bonds for SEK 500 million in 2013, expanding to SEK 1.8 billion in 2014, and SEK 1 billion both in 2015 and 2016 (UNFCCC, 2017). So far Gothenburg raised SEK 4.36 billion through financial markets. Green bonds are used for funding climate change mitigation $\&$ adaptation projects, adoption of low-carbon and clean technologies (e.g. cars that produce zero emissions or biogas project), as well more broad sustainability projects.

\section{Climate finance in Ukraine}

Achievements prior to Paris Agreement. Within Kyoto Protocol Ukraine become active only on the sixth year since of its implementation, being unable to sell $80 \%$ of its "hot" air, while becoming the greatest implementer of the JI projects, which however received a minor share of funding, compared to the CDM (Haidutskyi, 2016). In regards to general investments into climate related projects, based on the OECD analysis for 2013-2014, around USD 860 million annually came to Ukraine over this period. Most came from multilateral channels (over 10 times higher than bilateral) and in loans (77.8 \%), except of the finance from the Development Assistance Committee countries, which provided USD 60.7 million per year solemnly in grants (OECD, 2016 b). Climate-related development finance came from the European Bank for Reconstruction and Development USD 309 million per year, International Bank for Reconstruction and Development and European Investment Bank (both - USD 165 million per year), and Climate Investment Funds - USD 150 million per year.

In regards to domestic finance, since 2008 Ukraine has been developing and updating feed-in-tariff "the Green Tariff", directing finance to renewable energies (solar, wind, biomass and biogas) and simultaneously supporting the use of locally produced components (IEA\&IRENA, 2015). There is also a scheme providing grants to cover up to $20 \%$ of investments into gas boiler replacement with non-gas alternatives, so far USD 1.9 million have been allocated (EC, 2015). Declared plans for establishing a national Energy Efficiency Fund remain unclear (GoU, 2015 a).

Prospects for the future: towards a more comprehensive approach. Ukraine's intended nationally determined contribution (INDC for the Paris Agreement is "to not exceed $60 \%$ of 1990 GHG emissions level in 2030" with readiness to revise targets after "the restoration of its territorial integrity and state sovereignty as well as after the approval of the post-2020 socio-economic development strategies with account of investment mobilization" (GoU, $2015 \mathrm{~b}$ ). Most national experts consider these targets too mild and suggest $30 \%$ from the 1990 baseline (70 \% reduction) would be a more reasonable target, set at least for 2050 (Dombrovskyi \& Heletukha, 2016, for more detailed elaboration see Sidenko \& Veklych, 2016). Current "Concept for Realization of the National Policy in the Sphere of Climate Change" (CMU, 2016) remains a very general and declarative document, requiring much more careful elaboration.

One of the new interesting instruments for Ukrainian companies are innovation vouchers, which allow them "to get irrevocable financing for projects connected to decrease in energy consumption, decrease in carbon emissions and curbing down resource intensity of production" [author's translation from Ukrainian] (http://innovoucher.com.ua). European Bank for Reconstruction and Development within the FINTECC program and with finance from EU Neighborhood Facility has provided EUR one million that can be distributed among up to 50 companies who comply with abovementioned targets. The program can offer potential contributors support with funds for testing and certification of the innovations, research and design, patenting or continuous development of climate innovations.

Clima East (2017) registry lists a pending "Development of ETS in Ukraine" project funded by Government of Germany (BMUB) and implemented by GIZ. It is expected to start in 2017 (previous phases date back to 2012), with 
further duration to be determined. According to Caron Market Watch, if carbon markets are to contribute towards below $1.5^{\circ} \mathrm{C}$ goal "they must work to rapidly increase ambition and guarantee high environmental integrity" (CBM, 2016). This particularly pertinent in the light of what Sarah Bracking (2015) calls "virtual green economy" or "green economy spectacle", where in many cases climate finance explored through the lens of real life reveals "evidence of non-performing, degraded and simply non-existing wind farms, offsets, carbon-capture technologies and tree planting efforts" (p. 2352).

Many issues and solutions still remain outside the finance, requiring good governance and effective public involvement into experimentation and exploration of social, behavioral and cultural aspects of responses to climate change (Castán \& Bulkeley, 2013; Williams, 2017), finding proper balance between incremental and transformational change (Winkler \& Dubash, 2016), as well as achieving accurate definition of problems and the most appropriate scale for intervention, proper timing for different decisions and the best set of instruments needed to achieve relevant changes (Huitema et. al, 2016).

Conclusion. While internationally challenges remain for including adaptation into climate targets, in Ukraine the issue is particularly pertinent. Along commitment to equal priority of mitigation and adaptation, no targets or activities in regards to adaptation have been formulated within INDCs and no legislative or policy frameworks have been developed so far, except of a very general national policy concept, which comes along with almost absent financing of climate change adaptation. Optimism for the possible establishment of the internal carbon market ought to be balanced by results-oriented mechanisms of its functioning. Meanwhile, even the most advanced climate finance architecture won't solve the climate challenges without active participation of the public, thus comes to forefront the need to not only support "hard" infrastructure projects, but also social and cultural innovation and experimentation.

\section{References}

Bracking, S. (2015). Performativity in the Green Economy: how far does climate finance create a fictive economy? Third World Quarterly, 36(12), 2337-2357. doi:10.1080/01436597.2015.1086263

Cames, M., Harthan, R., Füssler, J., Lazarus, M., Lee, C., Erickson, P., \& Spalding-Fecher, R. (2016). How additional is the Clean Development Mechanism. Analysis of application of current tools and proposed alternatives. Oeko-Institut E. V. CLIMA.B.3/SERl2013/ $0026 r$.

Castán Broto, V., \& Bulkeley, H. (2013). A survey of urban climate change experiments in 100 cities. Global Environmental Change, 23, 92-102. doi:10.1016/j.gloenvcha.2012.07.00

CBM (2016). Carbon Markets in the Post Paris World. Carbon Market Watch Briefing. Retrieved April 26, 2017. Retrieved from: http://carbonmarketwatch.org

Clima East (2017). National and Regional Donor activity in climate change, water and energy, biodiversity and GHG emissions reduction in Ukraine. Country Proflie. Retrieved from: http://www.climaeast.eu/partner-countries/ukraine

CMU (2016). Pro skhvalennia Kontseptsii realizatsii derzhavnoi polityky u sferi zminy klimatu na period do 2030 roku [On Adoption of the Concept for National Climate Policy in the Sphere of Climate
Change]. Cabinet of Ministers of Ukraine. Order, Concept from 07.12.2016 № 932-r. [in Ukrainian].

Dombrovskyi, O. \& Heletukha, H. (2016). Paryzka klimatychna uhoda: Ukraini treba skorotyty vykydy na $70 \%$ [Paris Climate Agreement: Ukraine should cut emissions but $70 \%$ ]. Economic Truth. Retrieved April 26, 2017. Retrieved from: http://www.epravda.com.ua. [in Ukrainian].

EC (2015). Implementation of the EU-Ukraine Memorandum of Understanding on Energy Cooperation during 2014. European Commission. Retrieved April 26, 2017. Retrieved from: https://ec.europa.eu/

Falconer, A., \& Stadelmann, M. (2014). What is climate finance? Definitions to improve tracking and scale up climate finance. A CPI Brief, Climate Policy Initiative, Rep., 9 p.

GoU (2015a). Ukraine invites Sweden to join establishment of Energy Efficiency Fund, Web-portal of Ukrainian government. Retrieved April 26, 2017. Retrieved from: www.kmu.gov.ua/

GoU (2015b). Intended Nationally-Determined Contribution (INDC) of Ukraine to a New Global Climate Agreement, Government of Ukraine. Retrieved April 26, 2017. Retrieved from: http://www4.unfccc.int/

Haidutskyi, I. (2016). Kudy ydut kiostki hroshi [Where does the Kyoto money go]. Mirror of the Week. Retrieved April 26, 2017. Retrieved from: http://gazeta.dt.ua/. [in Ukrainian].

Huitema, D., Adger, W. N., Berkhout, F., Massey, E., Mazmanian, D., Munaretto, S., \&... Termeer, C. M. (2016). The governance of adaptation: choices, reasons, and effects. Introduction to the Special Feature. Ecology \& Society, 21(3), 627-641. doi:10.5751/ES08797-210337

IEA/IRENA (2017). Retrieved April 26, 2017. Retrieved from: https://www.iea.org/policiesandmeasures/

Impuls dlia Klimatychnykh Innovatsii [Impulse for the Climate Innovations]. Retrieved April 26, 2017. Retrieved from: http://innovoucher.com.ua/. [in Ukrainian]

Kollmuss, A., Schneider, M., \& Zhezherin, V. (2015). Has Joint Implementation reduced GHG emissions? Lessons learned for the design of carbon market mechanisms. Stockholm Environment Institute. Working paper 2015-07.

OECD (2016a). Financing Climate Action in Eastern Europe, the Caucasus and Central Asia. Green Finance and Investment, OECD Publishing, Paris. doi:10.1787/9789264266339-en

OECD (2016b). Financing Climate Action in Ukraine. Country study. Green Action Programme.

Roberts, J., \& Weikmans, R. (2017). Postface: fragmentation, failing trust and enduring tensions over what counts as climate finance. International Environmental Agreements: Politics, Law \& Economics, 17(1), 129-137. doi:10.1007/s10784-016-9347-4

Sidenko, V., Veklych, O. (2016). Ukraina i polityka protydii zmini klimatu: ekonomichnyi aspekt [Ukraine and the politics of tackling climate change: economic dimension]. Analytical report. Kyiv, 208 p. [in Ukrainian].

UNFCCC (2015). Paris Agreement. Decision 1/CP.21. Document FCCC/CP/2015/L.9/Rev.1. United Nations Office at Geneva, 25 p.

UNFCCC (2017). Gothenburg green bonds. Retrieved April 26, 2017. Retrieved from: http://unfccc.int/

Williams, J. (2017). Lost in translation: Translating low carbon experiments into new spatial contexts viewed through the mobile-transitions lens. Journal Of Cleaner Production, doi:10.1016/j.jclepro.2017.03.236

Winkler, H., \& Dubash, N. K. (2016). Who determines transformational change in development and climate finance? Climate Policy (Earthscan), 16(6), 783-791. doi:10.1080/14693062.2015.1033674

Xu, Y., Dong, Z., \& Wang, Y. (2016). Establishing a measurement, reporting, and verification system for climate finance in post-Paris agreement period. Chinese Journal Of Population Resources And Environment, 14(4), 235. 


\section{ФИНАНСИРОВАНИЕ МЕРОПРИЯТИЙ ПО ПРОТИВОДЕЙСТВИЮ ИЗМЕНЕНИЯМ КЛИМАТА В КОНТЕКСТЕ ПАРИЖСКОГО КЛИМАТИЧЕСКОГО СОГЛАШЕНИЯ: ВОЗМОЖНОСТИ И ПРЕДОСТОРОЖНОСТИ ДЛЯ УКРАИНЫ}

Принятие Парижского соглашения (2015) начало новый этап в поиске решений по смягчению и адаптации к глобальным изменениям климата. Соглашение привнесло важные коррективы в архитектуру и процедуры международного климатического финансирования как одного из ключевых инструментов поддержки необходимых мер. Рассмотрены принципиальные изменения в сфере климатического финансирования, которые произошли после принятия соглашения и их актуальность для Украины, где на климатическое финансирование возлагаются большие надежды со стороны органов власти, бизнеса и общественности. Учитывая поляризованную климатическую политику в Украине, акцент сделан на важных аспектах климатического финансирования, которые часто остаются без внимания аналитиков и ученых, а именно: необходимость поиска альтернатив механизмам компенсации выбросов, важность разработки системы признания, мониторинга и верификации эффективности мер по адаптации, а также важность поиска решений за пределами политики декарбонизации и соответственно - ориентированного на нее финансирования. На основе анализа мирового опыта предложено рассматривать финансирование и другие экономические инструменты как элементы трансформационных решений, которые, несмотря на свою потенциальную действенность, не являются панацеей. Климатическое финансирование должно не только создавать синергии в системе мер по изменению климата, но и не препятствовать системным общественным изменениям, которые требуют более существенных сдвигов, а не только выделения достаточного количества и рационального использования средств.

Ключевые слова: климатическое финансирование; углеродные рынки; политика декарбонизации; международная сотрудничество.

В. І. Соловій

\section{ФІНАНСУВАННЯ ЗАХОДІВ З ПРОТИДІЇ ЗМІНАМ КЛІМАТУ У КОНТЕКСТІ ПАРИЗЬКОЇ КЛІМАТИЧНОЇ УГОДИ: МОЖЛИВОСТІ ТА ПЕРЕСТОРОГИ ДЛЯ УКРАЇНИ}

Прийняття Паризької угоди (2015) започаткувало новий етап у пошуку рішень щодо пом'якшення та адаптації до глобальних змін клімату. Угода внесла важливі корективи в архітектуру та процедури міжнародного кліматичного фінансування як одного із ключових інструментів підтримки необхідних заходів. Розглянуто принципові зміни у сфері кліматичного фінансування, які відбулися після прийняття угоди та їх актуальність для України, де на кліматичне фінансування покладаються значні надії 3 боку органів влади, бізнесу та громадськості. Зважаючи на поляризовану кліматичну політику в Україні, акцент зроблено на важливих аспектах кліматичного фінансування, які часто залишаються поза увагою аналітиків та науковців, а саме: потребі пошуку альтернатив механізмам компенсації викидів, важливості розробки системи визнання, моніторингу та верифікації ефективності заходів з адаптації, а також важливості пошуку рішень за межами політики декарбонізації та відповідно - орієнтованого на неї фінансування. На основі аналізу світового досвіду запропоновано розглядати фінансування та інші економічні інструменти як елементи трансформаційних рішень, які, попри свою потенційну дієвість, не є панацеєю. Кліматичне фінансування має не лише творити синергії в системі заходів щодо змін клімату, але й не перешкоджати системним суспільним змінам, які потребують істотніших зрушень, а не лише виділення достатньої кількості і раціонального використання коштів.

Ключові слова: кліматичне фінансування; вуглецеві ринки; політика декарбонізації; міжнародна співпраця.

Інформація про авторів:

Соловій Віталій Ігорович, магістр, PhD студент, НЛтУ України, м. Львів, Україна.

Email: vitsoloviy@yahoo.com 